\title{
The Discovery of an Enantioselective Receptor for (-)-Adenosine from a Racemic Dynamic Combinatorial Library
}

\author{
Sharon M. Voshell, Stephen J. Lee ${ }^{\star \ddagger}$ and Michel R. Gagné* \\ ${ }^{*}$ U.S. Army Research Office, P.O. Box 12211, Research Triangle Park, NC 27709 \\ Department of Chemistry, University of North Carolina at Chapel Hill, Chapel Hill, NC 27599-3290
}

\section{Supplementary Information}

General Methods. Chemicals were purchased from Aldrich and used as received. HBTU (2-(1Hbenzotriazole-1-yl)-1,1,3,3-tetramethylaminium hexafluorophosphate) was purchased from Novabiochem. Triethylamine was distilled from calcium hydride under nitrogen and used immediately. 4-Carboxybenzaldehyde dimethoxy acetal was prepared from a literature procedure. ${ }^{1}$ Instead of recrystallization from boiling hexanes, the product was isolated by filtering through a pad of silica and eluting with 1:1 ethyl acetate/hexanes ( $83 \%$ yield). All stereoisomeric compounds were prepared in procedures analogous to the procedures reported for the racemic proline compounds. Synthetic intermediates were obtained as oils or foams from which complete solvent removal was not possible; where this was the case these compounds were not submitted for elemental analysis.

NMR spectra were recorded on either a Bruker Avance 300 or a Bruker Avance 400 spectrometer. Chemical shifts are reported in ppm and are referenced to the residual solvent peaks $\left({ }^{1} \mathrm{H}\right.$ and ${ }^{13} \mathrm{C}$ NMR). HPLC analysis was performed on a Hewlett-Packard Series 1100 instrument, using an Agilent Eclipse XDB-C18 column ( $4.6 \times 150 \mathrm{~mm})$ with gradient elution $(20 \%$ methanol/water for $5 \mathrm{~min}$ then gradient to $100 \%$ methanol over 25 minutes) at a flow rate of $1.0 \mathrm{~mL} / \mathrm{min}$. The injection volume for a DCL with a concentration of $1 \mathrm{mM}$ was typically $10 \mu \mathrm{L}$. UV absorbance chromatograms were recorded at wavelengths of 232 and $289 \mathrm{~nm}$. The laser polarimeter signal was recorded with a PDR-Chiral, Inc. Advanced Laser Polarimeter equipped with an $18 \mu \mathrm{L}$ flow cell. The data was analyzed using HP ChemStations. LCMS analysis was performed on a Hewlett-Packard Series 1100 instrument, using a Phenomenex Intersil 5u ODS-2 column $(4.6 \times 150 \mathrm{~mm})$ with the same gradient elution as above. The eluent was analyzed by an Agilent 1946D mass spectrometer in positive ion mode with the electrospray ionization source.

\footnotetext{
${ }^{1}$ Roberts, S. L.; Furlan, R. L. E.; Otto, S.; Sanders, J. K. M. Org. Biomol. Chem. 2003, 1, 1625-1633.
} 

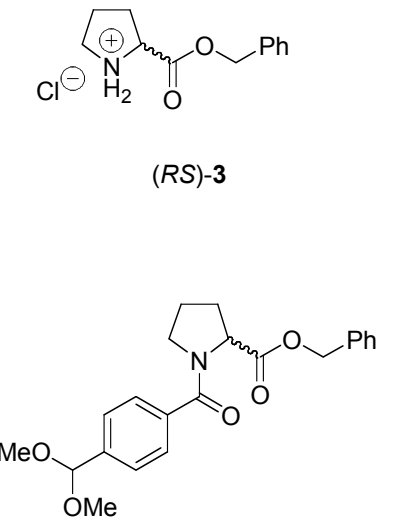

(RS)-4

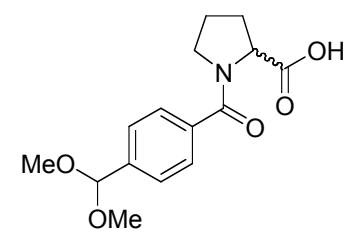

(RS)-5

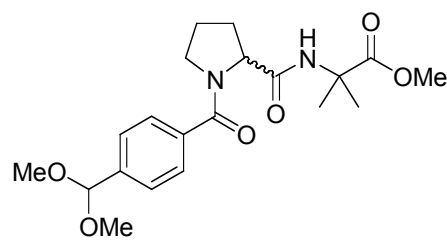

(RS)-6
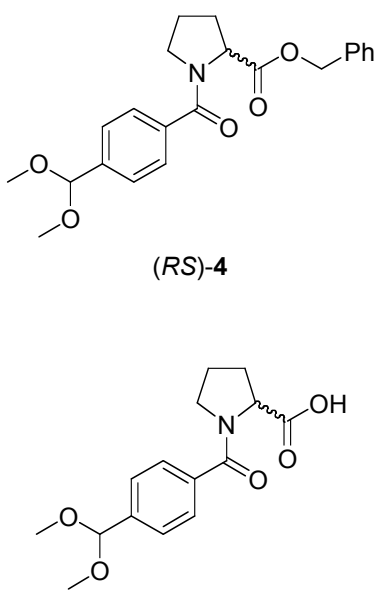

(RS)-5

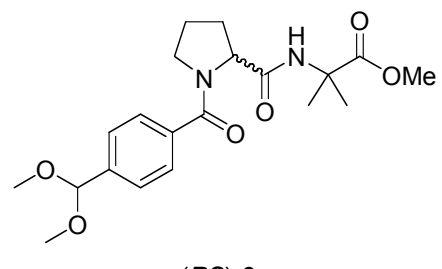

(RS)-6
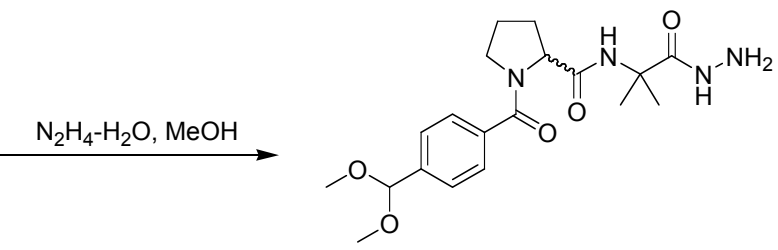

(RS)-1

(RS)-3. Benzyl alcohol $(70 \mathrm{~mL}, 651 \mathrm{mmol})$ was cooled to $0{ }^{\circ} \mathrm{C}$ under nitrogen and $7.0 \mathrm{~mL}$ thionyl chloride (91.2 mmol) was added. ( \pm )-Proline $(5.00 \mathrm{~g}, 43.4 \mathrm{mmol})$ was then added and the mixture was stirred at $0{ }^{\circ} \mathrm{C}$ under nitrogen for 2 hours. The mixture was warmed to room temperature and continued stirring for 48 hours. The solution was poured into $300 \mathrm{~mL}$ diethyl ether and stored at $-26^{\circ} \mathrm{C}$ for one week. The precipitate was collected by vacuum filtration, rinsed with diethyl ether, and dried in vacuo to a white solid (9.88 g, 93\% yield). ${ }^{1} \mathrm{H}$ NMR: (400 $\left.\mathrm{MHz}, \mathrm{CDCl}_{3}, \delta\right): 10.63$ (br, 1H), 9.21 (br, 1H), 7.29 (m, 5H), 5.21 (d, $\left.J=12.4 \mathrm{~Hz}, 1 \mathrm{H}\right), 5.14$ (d, $\left.J=12.4 \mathrm{~Hz}, 1 \mathrm{H}\right)$, $4.46(\mathrm{br}, 1 \mathrm{H}), 3.52(\mathrm{~m}, 1 \mathrm{H}), 3.44(\mathrm{~m}, 1 \mathrm{H}) 2.35(\mathrm{~m}, 1 \mathrm{H}), 2.11(\mathrm{~m}, 1 \mathrm{H}), 1.97(\mathrm{~m}, 2 \mathrm{H}) .{ }^{13} \mathrm{C} \mathrm{NMR}:\left(75.5 \mathrm{MHz}, \mathrm{CDCl}_{3}\right.$, б): $168.9,134.8,129.04,128.98,128.8,68.6,59.5,46.1,29.0,23.8$. Anal. Calcd for $\mathrm{C}_{12} \mathrm{H}_{16} \mathrm{ClNO}_{2}: \mathrm{C}, 59.63 ; \mathrm{H}$, 7.13; N, 5.79. Found: C, 59.03; H, 6.67; N, 6.01.

(R)-3. Benzyl alcohol $(32 \mathrm{~mL}, 325 \mathrm{mmol})$ was cooled to $0{ }^{\circ} \mathrm{C}$ under nitrogen and $3.5 \mathrm{~mL}$ thionyl chloride (45.6 mmol) was added. $(R)$-Proline $(2.50 \mathrm{~g}, 21.7 \mathrm{mmol})$ was then added and the mixture was stirred at $0{ }^{\circ} \mathrm{C}$ under 
nitrogen for 2 hours. The mixture was warmed to room temperature and continued stirring for 48 hours. The solution was poured into $150 \mathrm{~mL}$ diethyl ether and stored at $-26^{\circ} \mathrm{C}$ for one week. The precipitate was collected by vacuum filtration, rinsed with diethyl ether, and dried in vacuo to a white solid (4.44 g, 85\% yield). ${ }^{1} \mathrm{H}$ NMR: (400 $\left.\mathrm{MHz}, \mathrm{CDCl}_{3}, \delta\right): 10.62$ (br, 1H), 9.24 (br, 1H), 7.28 (m, 5H), 5.19 (d, $\left.J=12.0 \mathrm{~Hz}, 1 \mathrm{H}\right), 5.10$ (d, $\left.J=12.0 \mathrm{~Hz}, 1 \mathrm{H}\right)$, $4.46(\mathrm{br}, 1 \mathrm{H}), 3.51(\mathrm{~m}, 1 \mathrm{H}), 3.42(\mathrm{~m}, 1 \mathrm{H}), 2.33(\mathrm{~m}, 1 \mathrm{H}), 2.08(\mathrm{~m}, 1 \mathrm{H}), 1.97(\mathrm{~m}, 2 \mathrm{H}) .{ }^{13} \mathrm{C} \mathrm{NMR}:\left(75.5 \mathrm{MHz}, \mathrm{CDCl}_{3}\right.$,

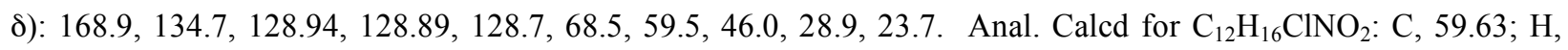
7.13; N, 5.79. Found: C, 59.47; H, 6.67; N, 5.69.

(RS)-4. 4-carboxybenzaldehyde dimethoxy acetal (2.38 g, $12.4 \mathrm{mmol})$, HBTU (4.71 g, $12.4 \mathrm{mmol})$, and 1hydroxybenzotriazole hydrate (HOBt, $1.69 \mathrm{~g}, 12.4 \mathrm{mmol})$ were dissolved in $60 \mathrm{~mL}$ DMF. (RS)-3 (3.00 g, 12.4 mmol) was added and the solution was stirred for 5 minutes before $5.2 \mathrm{~mL}(37.2 \mathrm{mmol})$ triethylamine was added. The solution was allowed to stir for 1.5 hours. Brine $(100 \mathrm{~mL})$ was added and the mixture was transferred to a separatory funnel. The mixture was extracted 3 times with $50 \mathrm{~mL}$ ethyl acetate. The combined organic extracts were washed three times with $100 \mathrm{~mL} 10 \%$ sodium bicarbonate, dried over magnesium sulfate, and filtered. The solvent was removed in vacuo to yield a red oil which was then chromatographed on silica using 5\% methanol in dichloromethane as an eluent $\left(\mathrm{R}_{\mathrm{f}}=0.37\right)$ to yield a yellow oil $(3.94 \mathrm{~g}, 83 \%$ yield $) .{ }^{1} \mathrm{H}$ NMR: $\left(400 \mathrm{MHz}, \mathrm{CDCl}_{3}, \delta\right)$ : $7.53(\mathrm{~d}, J=8.4 \mathrm{~Hz}, 2 \mathrm{H}), 7.47(\mathrm{~d}, J=8.4 \mathrm{~Hz}, 2 \mathrm{H}), 7.37-7.27(\mathrm{~m}, 5 \mathrm{H}), 5.39(\mathrm{~s}, 1 \mathrm{H}), 5.23(\mathrm{~d}, J=12.4 \mathrm{~Hz}, 1 \mathrm{H}), 5.16(\mathrm{~d}$, $J=12.4 \mathrm{~Hz}, 1 \mathrm{H}), 4.71(\mathrm{dd}, J=8.4 \mathrm{~Hz}, 5.2 \mathrm{~Hz}, 1 \mathrm{H}), 3.63-3.46(\mathrm{~m}, 2 \mathrm{H}), 3.30(\mathrm{~s}, 6 \mathrm{H}), 2.30(\mathrm{~m}, 1 \mathrm{H}), 1.96(\mathrm{~m}, 2 \mathrm{H}), 1.87$ (m, 1H). $\left.{ }^{13} \mathrm{C} \mathrm{NMR:} \mathrm{(75.5} \mathrm{MHz,} \mathrm{CDCl}_{3}, \delta\right): 172.3,169.7,140.4,136.6,136.1,128.9,128.5,128.4,127.5,127.0$, $102.9,67.2,59.6,53.0,50.2,29.7,25.7$.

(RS)-5. (RS)-4 (1.99 g, $5.22 \mathrm{mmol})$ was dissolved in $25 \mathrm{~mL}$ ethanol. Potassium carbonate $(0.72 \mathrm{~g}, 5.22$ mmol) and palladium on carbon (10 wt $\%, 0.58 \mathrm{~g})$ were added and the mixture was stirred overnight under an atmosphere of hydrogen. The mixture was filtered through celite and the solvent was removed from the filtrate in vacuo to yield a white foam (1.36 g, 89\% yield). ${ }^{1} \mathrm{H}$ NMR: (400 MHz, $\left.\mathrm{CDCl}_{3}, \delta\right): 7.45$ (d, $\left.J=8.0 \mathrm{~Hz}, 2 \mathrm{H}\right), 7.30$ (d, $J=8.0 \mathrm{~Hz}, 2 \mathrm{H}), 5.29(\mathrm{~s}, 1 \mathrm{H}), 4.13(\mathrm{t}, J=7.2 \mathrm{~Hz}, 1 \mathrm{H}), 3.61-3.42(\mathrm{~m}, 2 \mathrm{H}), 3.24(\mathrm{~s}, 6 \mathrm{H}), 1.98(\mathrm{~m}, 1 \mathrm{H}), 1.83(\mathrm{~m}, 1 \mathrm{H})$, $1.71(\mathrm{~m}, 1 \mathrm{H}), 1.43(\mathrm{~m}, 1 \mathrm{H}) .{ }^{13} \mathrm{C} \mathrm{NMR}:\left(75.5 \mathrm{MHz}, \mathrm{CDCl}_{3}, \delta\right): 178.2,169.3,139.6,137.6,127.5,126.7,102.9,63.4$, $53.0,50.7,30.1,25.8$.

(RS)-6. To a solution of HBTU (2.48 g, $6.46 \mathrm{mmol})$ and 1-hydroxybenzotriazole hydrate (HOBt, $0.88 \mathrm{~g}$, $6.46 \mathrm{mmol})$ in $20 \mathrm{~mL}$ DMF was added a solution of $(R S)-5(1.90 \mathrm{~g}, 6.46 \mathrm{~mL})$ in $30 \mathrm{~mL}$ DMF. The solution was 
stirred for 5 minutes and then $\alpha$-aminoisobutyric acid methyl ester hydrochloride $(0.99 \mathrm{~g}, 6.46 \mathrm{mmol})$ was added. The mixture was again stirred for 5 minutes and then $2.8 \mathrm{~mL}(19.4 \mathrm{mmol})$ triethylamine was added. The solution was allowed to stir for 1.5 hours. Brine $(50 \mathrm{~mL})$ was added and the mixture was transferred to a separatory funnel. The mixture was extracted 3 times with $50 \mathrm{~mL}$ ethyl acetate. The combined organic extracts were washed three

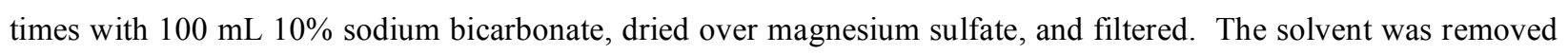
in vacuo to yield a yellow oil (1.62 g, 64\% yield). ${ }^{1} \mathrm{H}$ NMR: (400 MHz, $\left.\mathrm{CDCl}_{3}, \delta\right): 7.45$ (m, 4H), $5.34(\mathrm{~s}, 1 \mathrm{H}), 4.67$ (dd, $J=7.0,4.8 \mathrm{~Hz}, 1 \mathrm{H}), 3.65(\mathrm{~s}, 3 \mathrm{H}), 3.52-3.33(\mathrm{~m}, 2 \mathrm{H}), 3.25(\mathrm{~s}, 6 \mathrm{H}), 2.32(\mathrm{~m}, 1 \mathrm{H}), 1.95(\mathrm{~m}, 2 \mathrm{H}), 1.75(\mathrm{~m}, 1 \mathrm{H})$, 1.47 (s, 3H), 1.44 (s, 3H). ${ }^{13} \mathrm{C}$ NMR: (75.5 MHz, $\left.\mathrm{CDCl}_{3}, \delta\right):$ 175.0, 171.1, 170.4, 140.5, 136.6, 127.2, 127.0, 102.7, $59.9,56.5,52.9,50.6,38.8,27.2,25.5,25.12,25.06$.

(RS)-1. To a solution of $2.37 \mathrm{~g}(R S)-6$ in $3.0 \mathrm{~mL}$ methanol was added $3.0 \mathrm{~mL}$ hydrazine monohydrate. The solution was stirred overnight at room temperature. The solvent was then removed in vacuo and the yellow oil was chromatographed on silica using $10 \%$ methanol in dichloromethane as an eluent $\left(\mathrm{R}_{\mathrm{f}}=0.27\right)$ to yield a white solid (1.47 g, 62\% yield). ${ }^{1} \mathrm{H}$ NMR: $\left(400 \mathrm{MHz}, \mathrm{CDCl}_{3}, \delta\right): 8.32(\mathrm{br}, 1 \mathrm{H}), 7.55(\mathrm{~d}, J=8.4 \mathrm{~Hz}, 2 \mathrm{H}), 7.49(\mathrm{~d}, J=8.4 \mathrm{~Hz}$, 2H), 6.64 (br, 1H), 5.39 (s, 1H), $4.43(\mathrm{t}, J=6.4 \mathrm{~Hz}, 1 \mathrm{H}), 3.79$ (br, 2H), 3.62-3.52 (m, 2H), $3.31(\mathrm{~s}, 6 \mathrm{H}), 2.23(\mathrm{~m}$, 1H), $2.13(\mathrm{~m}, 2 \mathrm{H}), 1.84(\mathrm{~m}, 1 \mathrm{H}), 1.59(\mathrm{~s}, 3 \mathrm{H}), 1.50(\mathrm{~s}, 3 \mathrm{H}) .{ }^{13} \mathrm{C} \mathrm{NMR}:\left(75.5 \mathrm{MHz}, \mathrm{CDCl}_{3}, \delta\right): 174.9,171.7,171.2$ 141.0, 136.0, 127.6, 127.2, 102.8, 61.7, 57.2, 53.1, 51.0, 28.7, 27.4, 26.0, 25.0. Anal. Calcd for $\mathrm{C}_{19} \mathrm{H}_{28} \mathrm{~N}_{4} \mathrm{O}_{5}$ : C, 58.15; H, 7.19; N, 14.28. Found: C, 58.10; H, 7.34; N, 14.16 .

(S)-1. To a solution of $0.93 \mathrm{~g}(S)-6$ in $1.0 \mathrm{~mL}$ methanol was added $1.0 \mathrm{~mL}$ hydrazine monohydrate. The solution was stirred overnight at room temperature. The solvent was then removed in vacuo and the yellow oil was chromatographed on silica using $10 \%$ methanol in dichloromethane as an eluent $\left(\mathrm{R}_{\mathrm{f}}=0.27\right)$ to yield a white solid (0.56 g, 60\% yield). ${ }^{1} \mathrm{H}$ NMR: $\left(400 \mathrm{MHz}, \mathrm{CDCl}_{3}, \delta\right): 8.41(\mathrm{br}, 1 \mathrm{H}), 7.53(\mathrm{~d}, J=8.0 \mathrm{~Hz}, 2 \mathrm{H}), 7.47$ (d, $J=8.0 \mathrm{~Hz}$, 2H), $6.82(\mathrm{br}, 1 \mathrm{H}), 5.37(\mathrm{~s}, 1 \mathrm{H}), 4.41(\mathrm{t}, J=6.4 \mathrm{~Hz}, 1 \mathrm{H}), 3.70(\mathrm{br}, 2 \mathrm{H}), 3.62-3.47(\mathrm{~m}, 2 \mathrm{H}), 3.29(\mathrm{~s}, 6 \mathrm{H}), 2.13(\mathrm{~m}$, $3 \mathrm{H}), 1.81(\mathrm{~m}, 1 \mathrm{H}), 1.57$ (s, 3H), 1.46 (s, 3H). ${ }^{13} \mathrm{C} \mathrm{NMR}:\left(75.5 \mathrm{MHz}, \mathrm{CDCl}_{3}, \delta\right): 174.9,171.8,171.1,140.9,136.0$, 127.5, 127.1, 102.7, 61.6, 57.1, 53.1, 50.9, 28.8, 27.3, 25.9, 24.8. Anal. Calcd for $\mathrm{C}_{19} \mathrm{H}_{28} \mathrm{~N}_{4} \mathrm{O}_{5}$ : C, 58.15; H, 7.19; N, 14.28. Found: C, 58.21; H, 7.38; N, 14.29 .

(R)-1. To a solution of $0.98 \mathrm{~g}(R)-6$ in $1.0 \mathrm{~mL}$ methanol was added $1.0 \mathrm{~mL}$ hydrazine monohydrate. The solution was stirred overnight at room temperature. The solvent was then removed in vacuo and the yellow oil was chromatographed on silica using $10 \%$ methanol in dichloromethane as an eluent $\left(\mathrm{R}_{\mathrm{f}}=0.27\right)$ to yield a white solid 
(0.67 g, 68\% yield). ${ }^{1} \mathrm{H}$ NMR: $\left(400 \mathrm{MHz}, \mathrm{CDCl}_{3}, \delta\right): 8.39$ (br, $\left.1 \mathrm{H}\right), 7.53(\mathrm{~d}, J=8.0 \mathrm{~Hz}, 2 \mathrm{H}), 7.47(\mathrm{~d}, J=8.0 \mathrm{~Hz}$, 2H), $6.78(\mathrm{br}, 1 \mathrm{H}), 5.37(\mathrm{~s}, 1 \mathrm{H}), 4.41(\mathrm{t}, J=6.4 \mathrm{~Hz}, 1 \mathrm{H}), 3.70(\mathrm{br}, 2 \mathrm{H}), 3.62-3.50(\mathrm{~m}, 2 \mathrm{H}), 3.30(\mathrm{~s}, 6 \mathrm{H}), 2.13(\mathrm{~m}$, 3H), $1.82(\mathrm{~m}, 1 \mathrm{H}), 1.57$ (s, 3H), 1.47 (s, 3H). ${ }^{13} \mathrm{C} \mathrm{NMR}:\left(75.5 \mathrm{MHz}, \mathrm{CDCl}_{3}, \delta\right): 174.9,171.8,171.1,140.9,136.0$, 127.6, 127.1, 102.8, 61.6, 57.1, 53.1, 50.9, 28.8, 27.3, 25.9, 24.9. Anal. Calcd for $\mathrm{C}_{19} \mathrm{H}_{28} \mathrm{~N}_{4} \mathrm{O}_{5}: \mathrm{C}, 58.15 ; \mathrm{H}, 7.19 ; \mathrm{N}$, 14.28. Found: C, $58.07 ; \mathrm{H}, 6.91 ; \mathrm{N}, 14.40$.

$\mathbf{d}_{7}-(\boldsymbol{S})$-3. Benzyl alcohol $(1.5 \mathrm{~mL}, 12.3 \mathrm{mmol})$ was cooled to $0{ }^{\circ} \mathrm{C}$ under nitrogen and $0.13 \mathrm{~mL}$ thionyl chloride $(1.72 \mathrm{mmol})$ was added. $\mathrm{d}_{7}-(S)$-proline $(0.10 \mathrm{~g}, 0.819 \mathrm{mmol})$ was then added and the mixture was stirred at $0{ }^{\circ} \mathrm{C}$ under nitrogen for 2 hours. The mixture was warmed to room temperature and continued stirring for 48 hours. The solution was poured into $10 \mathrm{~mL}$ diethyl ether and stored at $-26^{\circ} \mathrm{C}$ for one week. The precipitate was collected by vacuum filtration, rinsed with diethyl ether, and dried in vacuo to give a white solid $(0.192 \mathrm{~g}, 92 \%$ yield $) .{ }^{1} \mathrm{H}$ NMR: (400 MHz, $\left.\mathrm{CDCl}_{3}, \delta\right): 10.82$ (br, 1H), $9.11(\mathrm{br}, 1 \mathrm{H}), 7.29$ (m, 5H), 5.23 (d, $\left.J=12.4 \mathrm{~Hz}, 1 \mathrm{H}\right), 5.15$ (d, $J=12.4$ Hz, 1H). ${ }^{13} \mathrm{C}$ NMR: (75.5 MHz, $\left.\mathrm{CDCl}_{3}, \delta\right): 169.0,134.8,129.15,129.06,128.9,68.8,59.1(\mathrm{~m}), 45.5(\mathrm{~m}), 28.3(\mathrm{~m})$, $22.9(\mathrm{~m})$.

$\mathbf{d}_{7}$-(S)-4. 4-carboxybenzaldehyde dimethoxy acetal (0.118 g, $\left.0.603 \mathrm{mmol}\right)$, HBTU (0.235 g, $\left.0.603 \mathrm{mmol}\right)$, and 1-hydroxybenzotriazole hydrate $(\mathrm{HOBt}, 87.0 \mathrm{mg}, 0.603 \mathrm{mmol})$ were dissolved in $5 \mathrm{~mL} \mathrm{DMF} . \mathrm{d}_{7}-(S)-3(0.152 \mathrm{~g}$, $0.603 \mathrm{mmol})$ was added and the solution was stirred for 5 minutes before $0.25 \mathrm{~mL}(1.81 \mathrm{mmol})$ triethylamine was added. The solution was allowed to stir for 1.5 hours. Brine $(5 \mathrm{~mL})$ was added and the mixture was transferred to a separatory funnel. The mixture was extracted 3 times with $5 \mathrm{~mL}$ ethyl acetate. The combined organic extracts were washed three times with $10 \mathrm{~mL} \mathrm{10 \%} \mathrm{sodium} \mathrm{bicarbonate,} \mathrm{dried} \mathrm{over} \mathrm{magnesium} \mathrm{sulfate,} \mathrm{and} \mathrm{filtered.} \mathrm{The} \mathrm{solvent}$ was removed in vacuo to yield a red oil which was then chromatographed on silica using $5 \%$ methanol in dichloromethane as an eluent $\left(\mathrm{R}_{\mathrm{f}}=0.37\right)$ to yield a yellow oil $(0.114 \mathrm{~g}, 48 \%$ yield $) .{ }^{1} \mathrm{H} \mathrm{NMR}$ : (400 MHz, $\mathrm{CDCl}_{3}$,

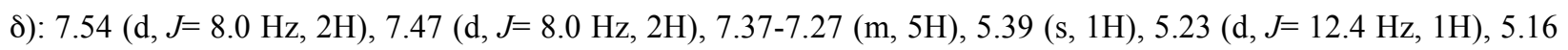
$(\mathrm{d}, J=12.4 \mathrm{~Hz}, 1 \mathrm{H}), 3.31(\mathrm{~s}, 6 \mathrm{H})$.

$\mathbf{d}_{7}-(S)-5 . \quad \mathrm{d}_{7}-(S)-4(0.114 \mathrm{~g}, 0.256 \mathrm{mmol})$ was dissolved in $3 \mathrm{~mL}$ ethanol. Potassium carbonate $(36.8 \mathrm{mg}$, $0.256 \mathrm{mmol})$ and palladium on carbon $(10 \mathrm{wt} \%, 30.2 \mathrm{~g})$ were added and the mixture was stirred overnight under an atmosphere of hydrogen. The mixture was filtered through celite and the solvent was removed from the filtrate in vacuo to yield a white foam (85.1 mg, 97\% yield). ${ }^{1} \mathrm{H}$ NMR: (400 MHz, $\left.\mathrm{CDCl}_{3}, \delta\right): 7.48$ (d, J=8.0 Hz, 2H), 7.32 (d, $J=8.0 \mathrm{~Hz}, 2 \mathrm{H}), 5.29(\mathrm{~s}, 1 \mathrm{H}), 3.25(\mathrm{~s}, 6 \mathrm{H})$. 
$\mathbf{d}_{7}$-(S)-6. To a solution of HBTU $(0.112 \mathrm{~g}, 0.292 \mathrm{mmol})$ and 1-hydroxybenzotriazole hydrate (HOBt, 41.7 $\mathrm{mg}, 0.292 \mathrm{mmol})$ in $1 \mathrm{~mL}$ DMF was added a solution of $\mathrm{d}_{7}-(S)-5(85.1 \mathrm{mg}, 0.292 \mathrm{mmol})$ in $1 \mathrm{~mL}$ DMF. The solution was stirred for 5 minutes and then $\alpha$-aminoisobutyric acid methyl ester hydrochloride (46.3 $\mathrm{mg}, 0.292$ mmol) was added. The mixture was again stirred for 5 minutes and then $0.15 \mathrm{~mL}(0.877 \mathrm{mmol})$ triethylamine was added. The solution was allowed to stir for 1.5 hours. Brine $(5 \mathrm{~mL})$ was added and the mixture was transferred to a separatory funnel. The mixture was extracted 3 times with $5 \mathrm{~mL}$ ethyl acetate. The combined organic extracts were

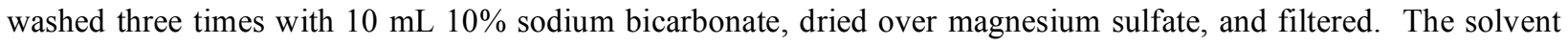
was removed in vacuo to yield a yellow oil $\left(83.1 \mathrm{mg}, 71 \%\right.$ yield). ${ }^{1} \mathrm{H}$ NMR: $\left(400 \mathrm{MHz}, \mathrm{CDCl}_{3}, \delta\right): 7.51(\mathrm{~m}, 4 \mathrm{H})$, $5.42(\mathrm{~s}, 1 \mathrm{H}), 3.73(\mathrm{~s}, 3 \mathrm{H}), 3.33(\mathrm{~s}, 6 \mathrm{H}), 1.52(\mathrm{~s}, 3 \mathrm{H}), 1.51(\mathrm{~s}, 3 \mathrm{H})$.

$\mathbf{d}_{7}-(\boldsymbol{S})-\mathbf{1}$. To a solution of $83.1 \mathrm{mg} \mathrm{d} \mathrm{d}_{7}-(S)-6$ in $0.10 \mathrm{~mL}$ methanol was added $0.1 \mathrm{~mL}$ hydrazine monohydrate. The solution was stirred overnight at room temperature. The solvent was then removed in vacuo and the yellow oil was chromatographed on silica using $10 \%$ methanol in dichloromethane as an eluent $\left(\mathrm{R}_{\mathrm{f}}=0.27\right)$ to yield a white solid (39.0 mg, 47\% yield, $16 \%$ based on $\left.(S)-3-\mathrm{d}_{7}\right) .{ }^{1} \mathrm{H}$ NMR: $\left(400 \mathrm{MHz}, \mathrm{CDCl}_{3}, \delta\right): 8.32(\mathrm{br}, 1 \mathrm{H})$, $7.55(\mathrm{~d}, J=8.0 \mathrm{~Hz}, 2 \mathrm{H}), 7.50(\mathrm{~d}, J=8.0 \mathrm{~Hz}, 2 \mathrm{H}), 6.60(\mathrm{br}, 1 \mathrm{H}), 5.39(\mathrm{~s}, 1 \mathrm{H}), 3.78(\mathrm{~d}, J=3.6 \mathrm{~Hz}, 2 \mathrm{H}), 3.32(\mathrm{~s}, 6 \mathrm{H})$, 1.59 (s, 3H), 1.49 (s, 3H). ${ }^{13} \mathrm{C}$ NMR: (75.5 MHz, $\left.\mathrm{CDCl}_{3}, \delta\right): 174.9,171.8,171.2,140.9,136.0,127.6,127.1,102.8$, $61.2(\mathrm{~m}), 57.1,53.1,50.4(\mathrm{~m}), 27.8(\mathrm{~m}), 27.4,25.6(\mathrm{~m}), 24.9$.

General procedure for the generation of DCLs. For HPLC analysis, 1 mM DCLs were prepared on a 1 mL scale. $(R S)-1(2.3 \mathrm{mg}, 5.9 \mu \mathrm{mol})$ was dissolved in $5.0 \mathrm{~mL} \mathrm{1 \%} \mathrm{2-methoxyethanol} \mathrm{in} \mathrm{dichloromethane} \mathrm{and} 20 \mu \mathrm{L}$ TFA was added. Aliquots of this solution $(1.0 \mathrm{~mL})$ were transferred to 2 vials and (-)-adenosine $(1.2 \mathrm{mg}, 4.5 \mu \mathrm{mol})$ was added to one of the vials. The solutions were allowed to sit overnight (12-16 hours) during which equilibrium was reached before HPLC analysis.

General procedure for isolation of static libraries. For mass spectroscopy, $1 \mathrm{mM}$ DCLs were generated and the exchange raction was quench by treating with base. These DCLs were generated on a 5.0 $\mathrm{mL}$ scale. (RS)-1 (3.9 mg, $9.94 \mu \mathrm{mol}$ ) was dissolved in $10.0 \mathrm{~mL} \mathrm{1 \%} \mathrm{2-methoxyethanol} \mathrm{in} \mathrm{dichloromethane} \mathrm{and} 40 \mathrm{uL}$ TFA was added. A $5.0 \mathrm{~mL}$ aliquot of this solution was transferred to a separate vial containing (-)-adenosine (6.9 $\mathrm{mg}, 25.8$ $\mu \mathrm{mol})$. The solutions were allowed to sit overnight (12-16 hours) during which equilibrium was reached. The samples were checked by HPLC to ensure DCL formation was complete. Amberlyst-A21 (2.0 g) was washed with $50 \mathrm{~mL}$ distilled water, $50 \mathrm{~mL}$ methanol, and $50 \mathrm{~mL}$ dichloromethane and added to the DCL. The mixture was 
allowed to stir for 5 minutes. The Amberlyst-A21 was removed by filtration and washed with $5 \mathrm{~mL}$ dichloromethane and $25 \mathrm{~mL}$ methanol. The filtrate solvent was removed in vacuo and the residue was redissolved in $1.0 \mathrm{mM}$ methanol (5 mM DCL) and subjected to HPLC analysis to ensure the library distribution was not affected by the quenching procedure.

Amplification of Dimer in Enantiopure Libraries (Figure 2a). Monomers (19.6 mg, $50 \mu \mathrm{mol})$ were weighed quantitatively and added to three separate $10-\mathrm{mL}$ volumetric flasks. Solvent (1\% 2methoxyethanol/dichloromethane) was added to dissolve the monomer ( $8 \mathrm{~mL})$. TFA $(0.19 \mathrm{~mL}, 2.5 \mathrm{mmol})$ was added to each flask and the solutions were diluted to the mark with solvent. Adenosine (5 eq. to monomer) was weighed into 2-mL HPLC vials according to the following table, and the solutions were diluted to the appropriate concentrations in the same vials (Table A below). The solutions were then allowed to sit overnight before HPLC analysis. The DCL composition for each solution is shown (Table B below). The increase in HPLC area percent for the dimer $\left(\Delta_{\text {dimer }}\right)$ was reported in Figure $2 \mathrm{a}$ in the text. 
Table A

\begin{tabular}{|c|c|c|c|c|}
\hline $\begin{array}{l}\text { Monomer } \\
\text { Enantiomer }\end{array}$ & $\begin{array}{c}\text { [Monomer] } \\
(\mathrm{mM})\end{array}$ & $\begin{array}{c}\text { Volume } \\
\text { Library } \\
(\mathrm{mL})\end{array}$ & $\begin{array}{c}\text { Volume } \\
\text { Solvent } \\
(\mathrm{mL})\end{array}$ & $\begin{array}{l}\text { Adenosine } \\
\quad(\mathrm{mg})\end{array}$ \\
\hline rac & 5.0 & 1.0 & 0.0 & 0.0 \\
\hline rac & 5.0 & 1.0 & 0.0 & 6.5 \\
\hline$S$ & 5.0 & 1.0 & 0.0 & 0.0 \\
\hline$S$ & 5.0 & 1.0 & 0.0 & 7.3 \\
\hline $\mathrm{R}$ & 5.0 & 1.0 & 0.0 & 0.0 \\
\hline $\mathrm{R}$ & 5.0 & 1.0 & 0.0 & 6.4 \\
\hline rac & 4.0 & 0.8 & 0.2 & 0.0 \\
\hline rac & 4.0 & 0.8 & 0.2 & 5.3 \\
\hline$S$ & 4.0 & 0.8 & 0.2 & 0.0 \\
\hline$S$ & 4.0 & 0.8 & 0.2 & 5.9 \\
\hline $\mathrm{R}$ & 4.0 & 0.8 & 0.2 & 0.0 \\
\hline $\mathrm{R}$ & 4.0 & 0.8 & 0.4 & 5.5 \\
\hline rac & 3.0 & 0.6 & 0.4 & 0.0 \\
\hline rac & 3.0 & 0.6 & 0.4 & 4.6 \\
\hline$S$ & 3.0 & 0.6 & 0.4 & 0.0 \\
\hline$S$ & 3.0 & 0.6 & 0.4 & 5.2 \\
\hline $\mathrm{R}$ & 3.0 & 0.6 & 0.4 & 0.0 \\
\hline $\mathrm{R}$ & 3.0 & 0.6 & 0.4 & 4.1 \\
\hline rac & 2.0 & 0.4 & 0.6 & 0.0 \\
\hline rac & 2.0 & 0.4 & 0.6 & 2.3 \\
\hline$S$ & 2.0 & 0.4 & 0.6 & 0.0 \\
\hline$S$ & 2.0 & 0.4 & 0.6 & 2.3 \\
\hline $\mathrm{R}$ & 2.0 & 0.4 & 0.6 & 0.0 \\
\hline $\mathrm{R}$ & 2.0 & 0.4 & 0.6 & 2.9 \\
\hline rac & 1.0 & 0.2 & 0.8 & 0.0 \\
\hline rac & 1.0 & 0.2 & 0.8 & 1.5 \\
\hline$S$ & 1.0 & 0.2 & 0.8 & 0.0 \\
\hline$S$ & 1.0 & 0.2 & 0.8 & 1.5 \\
\hline $\mathrm{R}$ & 1.0 & 0.2 & 0.8 & 0.0 \\
\hline $\mathrm{R}$ & 1.0 & 0.2 & 0.8 & 1.5 \\
\hline
\end{tabular}


Table B

\begin{tabular}{|c|c|c|c|c|c|c|c|}
\hline $\begin{array}{l}\text { Monomer } \\
\text { Enantiomer }\end{array}$ & $\begin{array}{c}\text { [Monomer] } \\
(\mathrm{mM})\end{array}$ & $\begin{array}{l}\text { Adenosine } \\
\text { (mg) }\end{array}$ & $\%$ Dimer & $\Delta_{\text {dimer }}$ & $\%$ Trimer & $\begin{array}{c}\% \\
\text { Tetramer }\end{array}$ & $\begin{array}{c}\% \\
\text { Hexamer }\end{array}$ \\
\hline rac & 5.0 & 0.0 & 36.7 & \multirow{2}{*}{11.2} & 32.0 & 23.9 & 7.4 \\
\hline rac & 5.0 & 6.5 & 47.9 & & 33.2 & 18.9 & 0.0 \\
\hline$S$ & 5.0 & 0.0 & 17.5 & \multirow{2}{*}{36.6} & 24.6 & 36.7 & 21.3 \\
\hline$S$ & 5.0 & 7.3 & 54.1 & & 24.8 & 18.9 & 2.2 \\
\hline $\mathrm{R}$ & 5.0 & 0.0 & 16.2 & \multirow{2}{*}{23.5} & 20.2 & 37.5 & 26.1 \\
\hline $\mathrm{R}$ & 5.0 & 6.4 & 39.7 & & 22.7 & 35.1 & 2.5 \\
\hline rac & 4.0 & 0.0 & 34.9 & \multirow{2}{*}{9.0} & 25.7 & 24.4 & 14.9 \\
\hline rac & 4.0 & 5.3 & 43.9 & & 31.6 & 20.7 & 3.8 \\
\hline$S$ & 4.0 & 0.0 & 16.2 & \multirow{2}{*}{36.0} & 18.5 & 37.1 & 28.1 \\
\hline$S$ & 4.0 & 5.9 & 52.2 & & 20.8 & 24.0 & 2.9 \\
\hline $\mathrm{R}$ & 4.0 & 0.0 & 14.9 & \multirow{2}{*}{18.9} & 15.5 & 38.5 & 31.2 \\
\hline $\mathrm{R}$ & 4.0 & 5.5 & 33.8 & & 17.8 & 45.3 & 3.0 \\
\hline rac & 3.0 & 0.0 & 32.9 & \multirow{2}{*}{8.9} & 21.7 & 24.2 & 21.1 \\
\hline rac & 3.0 & 4.6 & 41.8 & & 29.2 & 24.6 & 4.4 \\
\hline$S$ & 3.0 & 0.0 & 15.2 & \multirow{2}{*}{36.9} & 14.7 & 40.2 & 30.0 \\
\hline$S$ & 3.0 & 5.2 & 52.1 & & 16.1 & 29.2 & 2.5 \\
\hline $\mathrm{R}$ & 3.0 & 0.0 & 14.6 & \multirow{2}{*}{15.0} & 12.4 & 42.0 & 31.0 \\
\hline $\mathrm{R}$ & 3.0 & 4.1 & 29.6 & & 13.1 & 53.4 & 3.9 \\
\hline rac & 2.0 & 0.0 & 34.5 & \multirow{2}{*}{6.4} & 20.3 & 26.7 & 18.5 \\
\hline rac & 2.0 & 2.3 & 40.9 & & 27.3 & 27.4 & 4.4 \\
\hline$S$ & 2.0 & 0.0 & 18.3 & \multirow{2}{*}{31.9} & 13.7 & 45.3 & 22.7 \\
\hline$S$ & 2.0 & 2.3 & 50.2 & & 12.5 & 35.8 & 1.7 \\
\hline $\mathrm{R}$ & 2.0 & 0.0 & 17.2 & \multirow{2}{*}{10.3} & 12.1 & 49.9 & 20.8 \\
\hline $\mathrm{R}$ & 2.0 & 2.9 & 27.5 & & 10.0 & 57.1 & 5.4 \\
\hline rac & 1.0 & 0.0 & 42.8 & \multirow{2}{*}{3.5} & 21.8 & 28.5 & 6.9 \\
\hline rac & 1.0 & 1.5 & 46.3 & & 25.5 & 28.2 & 0.0 \\
\hline$S$ & 1.0 & 0.0 & 27.4 & \multirow{2}{*}{29.5} & 14.8 & 51.5 & 6.3 \\
\hline$S$ & 1.0 & 1.5 & 56.9 & & 10.9 & 32.1 & 0.0 \\
\hline $\mathrm{R}$ & 1.0 & 0.0 & 25.6 & \multirow{2}{*}{6.2} & 13.4 & 54.8 & 6.3 \\
\hline $\mathrm{R}$ & 1.0 & 1.5 & 31.8 & & 8.2 & 55.0 & 5.1 \\
\hline
\end{tabular}

Enantiomeric Excess of Dimer. Monomers $(19.6 \mathrm{mg}, 50 \mu \mathrm{mol})$ were weighed quantitatively and added to three separate $10-\mathrm{mL}$ volumetric flasks. Solvent (1\% 2-methoxyethanol/dichloromethane) was added to dissolve the monomer $(8 \mathrm{~mL})$. TFA $(0.19 \mathrm{~mL}, 2.5 \mathrm{mmol})$ was added to each flask and the solutions were diluted to the mark with solvent. The solutions were diluted into 2-mL HPLC vials as follows (Table C), and allowed to sit overnight before HPLC analysis. The height of the laser polarimeter peak and the height of the UV peak (absorbance at 289 $\mathrm{nm}$ ) was measured for the dimer and plotted as a ratio in Figure $2 \mathrm{~b}$ in the text. 
Table C

\begin{tabular}{cccccc}
\hline $\begin{array}{c}\text { Volume S } \\
\text { Solution } \\
(\mathrm{mL})\end{array}$ & $\begin{array}{c}\text { Volume R } \\
\text { Solution } \\
(\mathrm{mL})\end{array}$ & \% ee & UV Height & LP Height & LP/UV \\
\hline 0.9 & 0.1 & 80 & 419.1 & -147.0 & -0.35 \\
0.8 & 0.2 & 60 & 508.2 & -110.7 & -0.22 \\
0.7 & 0.3 & 40 & 574.9 & -79.9 & -0.14 \\
0.6 & 0.4 & 20 & 648.9 & -42.6 & -0.07 \\
0.4 & 0.6 & -20 & 641.6 & 44.6 & 0.07 \\
0.3 & 0.7 & -40 & 583.3 & 82.5 & 0.14 \\
0.2 & 0.8 & -60 & 505.6 & 122.0 & 0.24 \\
0.1 & 0.9 & -80 & 417.5 & 152.6 & 0.37 \\
\hline
\end{tabular}

Deuterium labeled libraries for MS analysis. Monomers $\mathrm{d}_{7}-(S)-1(5.1 \mathrm{mg}, 12.7 \mu \mathrm{mol})$ and $(R)-\mathbf{1}(5.0 \mathrm{mg}$, $12.7 \mu \mathrm{mol})$ were weighed into separate vials and dissolved in $12.0 \mathrm{~mL} 1 \%$ 2-methoxyethanol in dichloromethane. Aliquots of each these solutions $(5.0 \mathrm{~mL})$ were transferred to two separate vials and adenosine $(13.1 \mathrm{mg}, 50 \mu \mathrm{mol})$ was added to one vial. The solutions were allowed to site overnight before HPLC analysis (Figure A). The solutions were then quenched using the procedure reported above. The quenched libraries were then redissolved in methanol $(5.0 \mathrm{~mL})$ for LCMS analysis. Mass spectra were recorded throughout the elution of the dimer peak and averaged. The peak heights for the various $\mathrm{M}^{+}$dimeric species were measured.
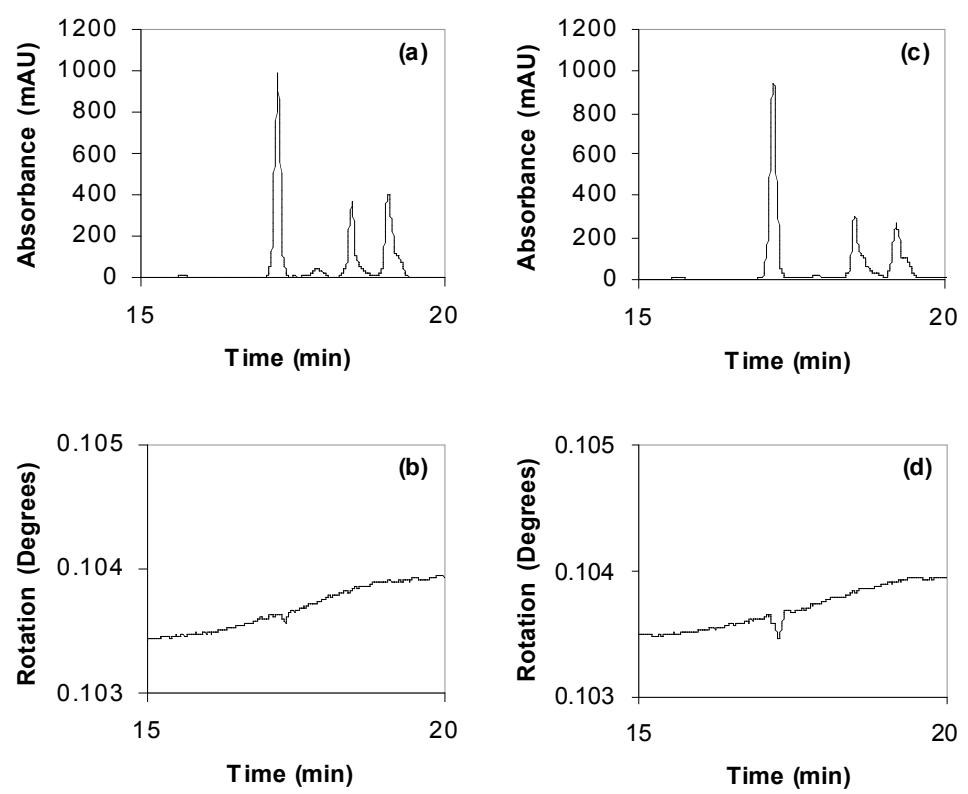

Figure A. (a) UV absorbance at $289 \mathrm{~nm}$ of untemplated $\mathrm{d}_{7}-(S)-\mathbf{1} /(R)-\mathbf{1} \mathrm{DCL}(1 \mathrm{mM}$ in monomer) (b) LP of untemplated $\mathrm{d}_{7}-(S)-\mathbf{1} /(R)-\mathbf{1}$ DCL (c) UV absorbance at $289 \mathrm{~nm}$ of $\mathrm{d}_{7}-(S)-\mathbf{1} /(R)-\mathbf{1} \mathrm{DCL}+(-)$-adenosine $(1 \mathrm{mM}$ monomer, $5 \mathrm{mM}$ adenosine) (d) LP of $\mathrm{d}_{7}-(S)-\mathbf{1} /(R)-\mathbf{1} \mathrm{DCL}+(-)$-adenosine. 
S11 